\title{
The Reform of Experiment Teaching System in Civil Engineering *
}

\author{
Yang Feng \\ School of Architectural and Civil Engineering East China \\ Institute of Technology \\ Nanchang 330013, China \\ Gao Jinhe \\ School of Architectural and Civil Engineering East China \\ Institute of Technology \\ Nanchang 330013, China
}

\author{
Liu Jun \\ School of Nuclear Engineering and Geophysics East China \\ Institute of Technology \\ Nanchang 330013, China \\ Cheng lihong \\ School of Architectural and Civil Engineering East China \\ Institute of Technology \\ Nanchang 330013, China
}

\begin{abstract}
Experimental teaching is the important teaching link of implementation of quality education and innovative talents training objectives. Based on the problems existing in the traditional experimental teaching system, this article analyzed the reasons. As well, in order to improve the practical ability and innovative spirits for students, the experimental teaching mode, experimental teaching mode and a new experimental teaching system and so on were researched in this article. Finally, it is proved that new experimental teaching systems had many advantages on capability of operating and practical engineering problems.
\end{abstract}

Keywords-practical ability; teaching mode; experiment teaching content; experimental teaching systems;

\section{INTRODUCTION}

Civil engineering major has the characteristics of strong theoretical and high demand of practical aspects, in order to meet with the construction industry, improving the comprehensive quality of students and developing a scientific way of thinking are the main direction of civil engineering specialty experiment teaching ${ }^{[1]}$. There are many main experimental courses, such as material mechanics, civil engineering materials, soil mechanics experiments, concrete structure design principle, etc. But these experiment courses have many disadvantages in forming independent experimental teaching system; having many verification and billing division of experiments, less of comprehensive, designing and researching for experiment ; the setting of experiment item and combining engineering practice ; highlighting the characteristics of civil engineering specialty experiment teaching and so on. Hence, it is important to improved the ability for students that the reforming of civil engineering specialty experiment teaching system ${ }^{[2]}$.

The current situation and existing problems of experimental teaching system for civil engineering experiment center in east china institute of technology, this article put forward to a new experimental teaching system. And it is proved that student's ability of start work and solve practical engineering problems has be obviously improved in the new experimental teaching system.

\section{THE PROBLEMS OF THE TRADITIONAL EXPERIMENT TEACHING SYSTEM}

Based on analysis the situation of civil engineering experiment center in east china institute of technology, there are mainly three aspects of the problem.

A. Closely linking between the experiment and theory, overlapping content of experiment, lack of correlation during experimental courses

Currently, because the experiment items are included in the theory courses for most institution, there are many disadvantages such as lack of correlation between each other, the single form, obsolescent contents and separation of related experiments and so on. As well, involved in the single test, the experiment content of the conventional theory course lacks of multi-disciplinary, multi-information, exploratory and development. The students make some tests; related to independent knowledge points, result in lacking of the understanding of the process, even some repeated tests. For example, the particle analysis test, the density and moisture of soil test are included in civil engineering materials, soil mechanics and foundation engineering; the tests of material mechanics, civil engineering materials and concrete structure design principle also are about the material property of steel and concrete ${ }^{[3]}$.

As well, because of the few experiment courses and independent experiment courses, it goes against improving students' awareness of engineering practice. The practical teaching plan for civil engineering in east china institute $f$ technology is showed in Table 1 . from table1, most core curriculum is in low proportion of total courses, such as material mechanics experiment is $11 \%$, civil engineering materials is $15 \%$, the structural mechanics is $7 \%$, which is far lower than the colleges in Europe and America, range from $30 \%$ to $40 \%$. 


\section{B. Single and subjectivity property of experiment grades criteria}

In order to examine the effect of teaching and experiment, the experimental teaching evaluation is intuitive, practical, comprehensive and innovative. But experimental examination scores are not important in the east china institute of technology, because the grades do not include the experiment examination scores. If the students take part in the experiment, they must pass the exam. Hence, the experiment grade is to adjust the pass rate, and can not truly reflect the actual performance of students, lack of fairness ${ }^{[4]}$.

\section{Simple teaching methods, the most confirmatory and demonstration experiment course}

The experiment system in most colleges has many disadvantages, such as obsolescent content, poor conditions, most confirmatory and demonstration experiment course, the tests, detaching with engineering. In addition, because of most experimental instruction correspond to the verification and demonstration experiments, which concludes the purposes, contents, steps of experiment, most teaching methods are inoculative methods, lack of interaction between students and teachers. And the students have few chances to operate the equipments to found and solve the problems. Hence, the independent and innovation for students are limited ${ }^{[5]}$

TABLE I. 2011 EDITION OF CIVIL ENGINEERING PRACTICE TEACHING PROGRAM OF EAST CHINA INSTITUTE OF TECHNOLOGY

\begin{tabular}{|c|c|c|c|c|c|}
\hline NO & $\begin{array}{c}\text { experimental } \\
\text { course }\end{array}$ & $\begin{array}{c}\text { belongs } \\
\text { module name }\end{array}$ & $\begin{array}{c}\text { experimental } \\
\text { hours }\end{array}$ & $\begin{array}{c}\text { total } \\
\text { hours }\end{array}$ & $\begin{array}{c}\text { the } \\
\text { proportion }\end{array}$ \\
\hline 1 & $\begin{array}{c}\text { engineering } \\
\text { survey }\end{array}$ & $\begin{array}{c}\text { professional } \\
\text { skills }\end{array}$ & 8 & 38 & $21 \%$ \\
\hline 3 & $\begin{array}{c}\text { civil } \\
\text { engineering } \\
\text { materials }\end{array}$ & $\begin{array}{l}\text { professional } \\
\text { skills }\end{array}$ & 6 & 38 & $15 \%$ \\
\hline 4 & $\begin{array}{l}\text { structural } \\
\text { mechanics }\end{array}$ & $\begin{array}{c}\text { professional } \\
\text { skills }\end{array}$ & 6 & 76 & $7 \%$ \\
\hline 5 & $\begin{array}{c}\text { civil } \\
\text { engineering } \\
\text { CAD }\end{array}$ & $\begin{array}{l}\text { professional } \\
\text { skills }\end{array}$ & 14 & 30 & $46 \%$ \\
\hline 2 & $\begin{array}{l}\text { mechanics of } \\
\text { materials }\end{array}$ & $\begin{array}{c}\text { professional } \\
\text { skills }\end{array}$ & 8 & 68 & $11 \%$ \\
\hline 7 & $\begin{array}{c}\text { fluid } \\
\text { mechanics }\end{array}$ & $\begin{array}{c}\text { professional } \\
\text { skills }\end{array}$ & 6 & 46 & $13 \%$ \\
\hline 8 & $\begin{array}{c}\text { concrete } \\
\text { structure } \\
\text { design } \\
\text { principle }\end{array}$ & $\begin{array}{l}\text { professional } \\
\text { skills }\end{array}$ & 6 & 68 & $8 \%$ \\
\hline 6 & $\begin{array}{l}\text { structural } \\
\text { dynamics }\end{array}$ & $\begin{array}{c}\text { professional } \\
\text { skills }\end{array}$ & 4 & 30 & $13 \%$ \\
\hline 10 & $\begin{array}{c}\text { soil mechanics } \\
\text { and } \\
\text { foundation } \\
\end{array}$ & $\begin{array}{l}\text { professional } \\
\text { skills }\end{array}$ & 6 & 54 & $11 \%$ \\
\hline 9 & $\begin{array}{c}\text { steel structure } \\
\text { design } \\
\text { principle } \\
\end{array}$ & $\begin{array}{l}\text { professional } \\
\text { skills }\end{array}$ & 6 & 46 & $13 \%$ \\
\hline 12 & $\begin{array}{c}\text { seismic design } \\
\text { of buildings }\end{array}$ & $\begin{array}{c}\text { professional } \\
\text { skills }\end{array}$ & 6 & 38 & $15 \%$ \\
\hline 11 & $\begin{array}{c}\text { concrete } \\
\text { structure and } \\
\text { masonry } \\
\text { structure } \\
\text { design } \\
\end{array}$ & $\begin{array}{l}\text { professional } \\
\text { skills }\end{array}$ & 6 & 38 & $15 \%$ \\
\hline \multicolumn{2}{|c|}{$\begin{array}{l}\text { building structure } \\
\text { experiment } \\
\text { technology }\end{array}$} & $\begin{array}{c}\text { professional } \\
\text { comprehensive }\end{array}$ & 18 & 30 & $60 \%$ \\
\hline
\end{tabular}

\section{CAUSES}

Civil engineering specialty is one of the major and practical majors in theory and practice in Colleges and universities. And it not only requires students to have solid knowledge of mechanics, but also has strong engineering practice ability. During experiment teaching, how to improve students' engineering practice ability is an important subject in Civil Engineering Specialty in engineering colleges and universities. However, in view of the current situation of the experimental teaching of civil engineering specialty, there are mainly two aspects.

On the one hand, many Colleges and universities do not pay attention to experiment teaching, and teachers are lack of enthusiasm. There are many reasons such as subordinated to theory teaching, the lower treatment, the few laboratory technicians, and the onerous teaching task. For example, there are 2 full-time laboratory technicians in east China institute of technology of experimental center of civil engineering and the two teachers have not high enthusiasm for the low salary, and many experiment tasks. So they may spend more time to do some research about civil engineering.

On the other hand, the experimental condition is poor; the students' learning enthusiasm is not high. Due to the small laboratory, little experimental funds, experimental center in civil engineering have few obsolete equipments. Although some colleges purchase some new equipments, which mainly are used to scientific researches. Hence, experimental conditions result in less than $100 \%$ of the opening rate of experimental course, some canceled necessary experiment.

\section{SOLUTION}

According to the main problems of the civil engineering teaching system in the school of civil engineering, the articles have put forward some reforms ${ }^{[6]}$.

\section{A. Integrations of experimental teaching contents and establishment of the new syllabus}

Based on the projection of Civil Engineering Specialty Experiment Teaching Reform and Practice Research in Jiangxi Province, the new experiment course system of civil engineering, showed in Fig 1, have be constructed by integrating and classifying the contents. According to the new teaching system, in order to guarantee the quantity of experiment item and class hours, the new teaching system and textbooks are set up. By practice research, there are many advantages such as grasping the necessary experimental method and basic experimental equipment operation skills, analyzing the experimental results, training students' rigorous scientific style and so on. And the new teaching system demands that student must master 3 basic elements. 


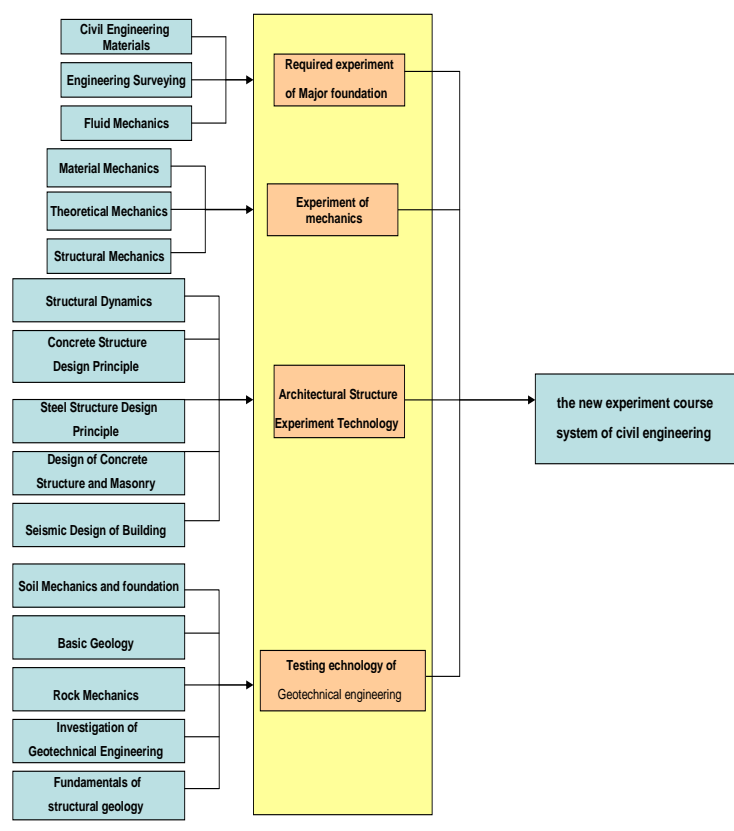

Fig. 1. Civil engineering experiment teaching system framework

(1) Basic knowledge and skills: mastering the using method of some equipment such as theodolite, level, mortar mixer and so on; grasping the skills for example making the mortar, concrete block and so on; familiaring the test standard.

(2) Opening experiment: mastering the comprehensive designing experiment such as the surveying scheme, concrete mixture ratio design and so on; Encouraging students to engage in engineering to improve the ability of designing, applying professional knowledge and solving problems.

(3) Innovative experiments: utilizing extracurricular science and technology competitions, college students practice innovation projects, research projects to cultivate students' scientific research ability.

\section{B. The reform of the experimental teaching method}

Because of intuitive, practical, comprehensive and creative characteristics, Experimental teaching is an important part of the implementation of quality education.

(1) Utilization of modern teaching means and abundant teaching content

Because of characteristics of the long periods, many consumable materials and high danger, the teaching mode of most colleges and universities is the teachers' demonstration, students with repeated practice. Doing not use multimedia teaching can not meet the requirement for the student beginning ability, innovation ability training. For example, the teacher guide students to observe the experiment phenomenon by playing the related experimental animations and videos, made and collect by teachers in advance. In addition, the computer simulation software can show the corresponding experimental animation and the changes of material property during the test. These animations and videos have many advantages of distinct, vivid, repeated use, save time, and achieving expected effect of experiment, the experimental class, effectively extended both in time and space.

\section{(2) Opening experiment teaching}

After completing the required tasks at states of high quality and high efficiency, some students can go to the opening laboratory to do some tests. Fig 2 showed that some students in east china institute of technology are making some test by themselves. These methods can satisfy student's desire for seeking knowledge, exploration and innovation, student's beginning ability is greatly improved.
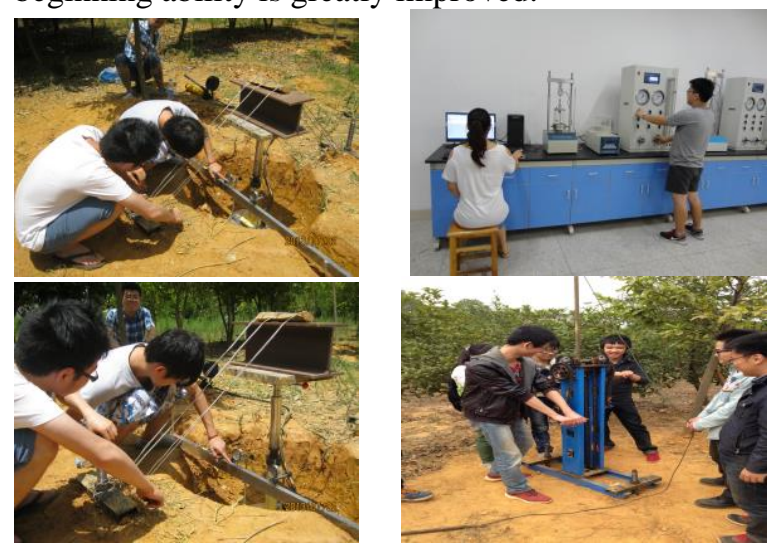

Fig. 2. making experiments on field

\section{ESTABLISH OF NEW EXPERIMENT ASSESSING SYSTEM}

Based on the problems of east china institute of technology Civil Engineering College, that is lack of fairness and can not really reflect students' real performance, the papers set up a new experimental examination system to fully reflect the students' learning level. And the reformed examination assessment system is showed in table 2 .

TABLE II.

EXPERIMENTAL TEACHING ASSESSMENT SYSTEM

\begin{tabular}{|c|c|c|c|}
\hline project & Check point & score & sum \\
\hline \multirow{3}{*}{ preview } & Prepare a report & 5 & \multirow{3}{*}{15} \\
\hline & Oral questions & 5 & \\
\hline & $\begin{array}{l}\text { The knowledge of the theory of the } \\
\text { experimen }\end{array}$ & 5 & \\
\hline \multirow{3}{*}{$\begin{array}{l}\text { experimental } \\
\text { process }\end{array}$} & Experimental attitude, team spirit & 5 & \multirow{3}{*}{45} \\
\hline & Operating standards & 20 & \\
\hline & The experimental troubleshooting skills & 20 & \\
\hline \multirow{4}{*}{ Lab report } & $\begin{array}{l}\text { The report format, and degree of } \\
\text { standardization }\end{array}$ & 5 & \multirow{4}{*}{25} \\
\hline & $\begin{array}{l}\text { The experiment understanding and written } \\
\text { expression ability }\end{array}$ & 5 & \\
\hline & Ability to observe record & 5 & \\
\hline & $\begin{array}{c}\text { Ability to analysis the result of the } \\
\text { experiment }\end{array}$ & 10 & \\
\hline \multirow{3}{*}{$\begin{array}{l}\text { The } \\
\text { experimental } \\
\text { communication }\end{array}$} & $\begin{array}{l}\text { Understanding and language expression } \\
\text { ability }\end{array}$ & 5 & \multirow{3}{*}{15} \\
\hline & Ask questions and problem solving ability & 5 & \\
\hline & $\begin{array}{c}\text { Comprehensive experiment method and } \\
\text { innovation ability }\end{array}$ & 5 & \\
\hline \multicolumn{3}{|c|}{ total } & 100 \\
\hline
\end{tabular}




\section{CONCLUSION}

Combining with the actual situation of civil engineering experiment center in east china institute of technology, this article had analyzed the problems existing in the traditional experiment teaching system and the reasons, taken out the solutions of integrating experiment teaching content, arranging the syllabus and textbooks, reforming the teaching method and setting up experiment assessing system. Finally, it is proved that the new teaching system can improve the ability of using hand and solving practical engineering problems.

\section{ACKNOWLEDGMENT}

This work was financially supported by the project of experiment teaching reform and practice research in civil engineering major, the reform project of Jiang xi province (JXJG-13-6-19, JXJG-12-8-9).

\section{REFERENCES}

[1] Zhang Mei, Pan Zhizhong, Zhao Yan。 Analysis on reform in practical teaching of civil engineering major. Journal of Shenyang jianzhu University (Social Science), 2008, 10(3):373-375.

[2] Li Li, Xiong Shi-shu, Ye Kun. Experiment teaching system and experiment project innovation of civil engineering. Journal of architectural education in institutions of high learner. 2010,19 (6): 141 143.

[3] Zeng Kaihua Gao Guiqing Ju Haiyan. Exploration and construction of experimental education system for applied civil engineering. Science and Technology Innovation Herald. 2014,29:194-196.

[4] Qin Zhiqian, Lei Lin. ODiscussion on experimentation teaching reforming of civil engineering profession. ShanXi Architecture, 2008,11(33):212-213.

[5] Qian Hongping Li Shujin Shi Guicai. Construction and Practice of a novel experimental teaching system for civil engineering. Research and exploration in laboratory, 2012, 31(10):122-125.

[6] Lai Zhenhua. On experimental teaching reform and practice of ivil engineering major. Research and exploration in laboratory,2010,29(11): 319-321 